disputas pelo poder, pelo prestígio ou por privilégios de vários tipos e pela atribuição a elas de um estatuto ambíguo, como se tratasse de seres andróginos a quem é preciso conjurar, desmentir, redefinir tão logo essa atribuição se expresse nos discursos a respeito de seus feitos científicos. Movimento de estranhamento, primeiro (que faz essa mulher num grupo de homens? Deve ser homem...), de re-alocação, em seguida (mas vejam que belo chapéu... feminino), logo de desqualificação (sendo mulher... não poderia ser cientista - ou viceversa.) (p. 30). ${ }^{1}$

O livro mapeia a trajetória dessas mulheres exemplares, e a luta de produção de sentido em torno do que elas faziam, principalmente pelos seus interlocutores masculinos, procurando situálas no contexto da atuação de outras mulheres contemporâneas na Antropologia em outros lugares do mundo. Essa luta semântica e política manifesta-se em termos literários e também nos relatos históricos sobre essas personagens: a naturalista Emilia Snethlage, a sertanista Leolinda Daltro e a pesquisadora de museu Heloisa Alberto Torres. A pergunta central, na análise dessas trajetórias, é: que diferença há em conjugar uma carreira no feminino? Há diferenças, sim, e isso é demonstrado ao longo de todo o livro. Diferenças essas que, via de regra, desvalorizam o trabalho feito por mulheres.

Outras questões emergem nos demais capítulos, como o entrelaçamento entre raça e gênero na política e teoria antropológica, e a atuação de outras mulheres na constituição da história da Antropologia. O livro Antropólogas \& Antropologia demonstra um exaustivo trabalho de pesquisa, que se manifesta em detalhes minuciosos (que incluem notas extensas de cunho explicativo e teórico) sobre a vida dessas mulheres e as narrativas a elas associadas, nos fazendo ser capturadas por tais trajetórias e pela forma de narrar da própria autora. O livro (fugindo de qualquer tipo de vitimização ou essencialismo das mulheres) é, sem dúvida, uma importante contribuição para os estudos de gênero no Brasil.

\begin{abstract}
1 Esses qualificativos que colocam em dúvida a competência profissional das mulheres não é uma exclusividade do campo da Antropologia. Ver, por exemplo, os comentários misóginos de artistas de renome sobre mulheres artistas. $O$ artista francês Renoir teria dito: "Considero as escritoras, advogadas e políticas - como Georges Sand, Madame Adam e outras - como monstros, como terneiros de cinco patas [...] A mulher artista é sinceramente ridícula". Ou ainda Degas, sobre a artista impressionista americana Mary Cassat: "Não posso admitir que uma mulher desenhe tão bem!" (Citados por PORQUERES, Bea. "Reconstruir uma tradición: las artistas em el mundo ocidental". Cuadernos Inacabados, Madrid: Horas y Horas, n. 13, 1994.
\end{abstract}

Luciana Gruppelli Loponte Universidade de Santa Cruz do Sul

\title{
A sexualidade depois da festa
}

\section{La sexualité ef l'histoire.}

\section{Yvonne Knibiehler.}

Paris: Ed. Odile Jacob, 2002. 268 p.

Em um momento em que se constata a presença das mulheres no mundo público, feminizando a cultura, a conhecida historiadora Yvonne Knibiehler lança um contundente desafio: como podem as mulheres contribuir para avançar as reflexões sobre as questões da sexualidade, em especial, no que tange às relações entre os sexos e à educação sexual dos jovens, quando a festa liberadora da Revolução sexual acabou? Como construir, no presente, uma educação dos jovens voltada para a sexualidade e para a vida?

Suas respostas aparecem claramente expostas nesse livro erudito e polêmico, que examina, com muita acuidade, o repertório sobre a sexualidade legado pela tradição ocidental, da Antigüidade greco-romana aos nossos dias, pois a autora está convencida de que se podem encontrar, na experiência do passado, chaves importantes para problematizar nossa atualidade. Como ela diz, "o relato histórico permite começar a pensar [...] A história é indispensável para a 'educação para a vida'” (p.15).

Trata-se, portanto, de um importante trabalho de intervenção social e política, em que Knibiehler procura dar sua contribuição, 
questionando e relativizando as conquistas sexuais, a liberação das mulheres, os discursos do gênero, a relação libertária dos pais com os filhos, mostrando seus limites, sem medo de exporse. Afinal, essa atitude crítica em relação às conquistas no terreno da sexualidade e do feminismo poderia evocar um certo conservadorismo, fato que leva muitos a silenciarem sobre os problemas contemporâneos.

Enfrentando corajosamente o desafio, a historiadora constrói um quadro pouco animador. Destaca, nos últimos 30 anos, o aumento do assédio sexual, da violência doméstica, do estupro e da prostituição forçada, o crescimento da gravidez de moças inexperientes e o descomprometimento dos homens em relação à gravidez indesejada, já que o aborto foi descriminalizado, e questiona os limites da emancipação feminina, considerando que grande parte das mulheres continua a se pensar a partir da linguagem masculina e a internalizar o desejo dos homens.

Em relação ao culturalismo e às questões do gênero, suas críticas não são menos radicais, pois acredita que, embora possamos pensar as relações entre os sexos como construções sociais e culturais, desfazendo as representações essencialistas da necessidade biológica inscrita nos corpos, e muito embora uma certa paridade tenha sido de fato conquistada, surgiram novas desigualdades entre os sexos, visíveis, por exemplo, na raridade da presença feminina nos cargos de direção, nas instituições, nas empresas, ou no Estado. Em suma, constata a autora, nem as hierarquias sexuais, nem os preconceitos acabaram; ao contrário, renovaram-se, diversificaram-se e intensificaram-se.

Nos seis capítulos que compõem o livro, em que Knibiehler trata de temas como os jovens, os casais, os amores, os "gêneros", as violências e os pais, emerge um amplo leque de experiências históricas da sexualidade, de formas de interpretação dos códigos morais, de problematizações e soluções inventadas por nossos antepassados, dos gregos aos modernos, chegando às transformações dos últimos 30 anos. Não se trata, contudo, apenas de uma reavaliação histórica do passado, pois a historiadora procura aclarar certos conceitos, mostrando sua historicidade, além da preocupação constante em não se limitar à leitura histórica das formas de controle e normatização, olhando também para as transgressões ao poder, especialmente por parte das mulheres, entre cortesãs, prostitutas, parteiras e intelectuais.
Nesse percurso, o livro mostra a constituição de uma relação profundamente problemática, difícil e repressiva na experiência da sexualidade do mundo ocidental. Da liberdade, na Grécia antiga, em que os jovens podiam ter relacionamentos sexuais com parceiros do mesmo sexo, passa-se, no cristianismo, a condenar a sexualidade como maldita para todos. A associação do sexo com a morte favorece a emergência da confissão no século 17, a demonização da masturbação no século seguinte, e sua crescente condenação pela Igreja, que recomenda a purificação da alma através de uma hermenêutica de si, como tão bem apontou Foucault. O nascimento da pucelle, por sua vez, só se torna possível quando a idade do casamento é retardada para as jovens, enquanto os rapazes, ensinados nos colégios a refrearem os instintos sexuais perigosos, encontram paradoxalmente na difusão dos bordéis as formas de iniciação sexual valorizadas.

Quanto ao casal ocidental, invenção dos hebreus e não dos gregos, Knibiehler constata que a dissociação do casamento da reprodução não facilitou sua vida. Na história da dominação masculina e do casamento, da Grécia aos nossos dias, nada impediu a liberdade sexual do 'sexo forte", enquanto que a mulher foi considerada um ser não-livre, já que, estando seu corpo sujeito à penetração e à procriação, ela não teria possibilidades de escolha. A relação heterosexual foi sempre assimétrica, enquanto a subordinação da esposa foi justificada pela sua inferioridade biológica, apesar das manifestações das transgressoras e rebeldes, como a cortesã Aspásia, admirada mais por sua inteligência que beleza.

Embora a Revolução Francesa tenha promovido a secularização do casamento e o divórcio, a contrapartida foi a invenção da 'natureza feminina', condenando o desejo feminino como perigo de histeria ou ninfomania, como já apontara a historiadora em seu livro pioneiro, Les femmes et les médecins. Toda essa trajetória de dificuldades aparece na literatura do século 19, onde os casais infelizes ganham a cena. E mesmo com a emancipação feminina, o casal igualitário continua uma 'utopia feminista'. Enfim, conclui a autora, o casal se "desinstitucionalizou" com a liberação sexual, os jovens se unem por algum tempo sem casar, cresce a solidão individual e, com a pílula, "o esperma perde seu poder mágico". Como, então, o casal poderá sobreviver, quando a reprodução e a educação dos filhos perdem sua importância? 
Em relação aos amores, Knibiehler encontra uma tradição também negativa, do cristianismo ao marxismo, em que se valoriza muito mais o esforço coletivo do que os prazeres individuais. No empenho de refrear a sexualidade, os ocidentais criaram abismos entre o amor carnal e o espiritual, estigmatizando os prazeres com o pecado e a culpa. Hoje, ao contrário, denunciase a "tirania do prazer", mas aumenta a mercantilização do corpo e "a tristeza do sexo". O que quer dizer amar, então?, pergunta ela.

É, portanto, na conclusão que a autora explicita brevemente suas propostas "utópicas", contribuindo para a criação de um projeto de educação dos jovens voltada para a sexualidade e para a vida. Sua perspectiva é a defesa do modelo republicano, do ideal de cidadania e da luta pelos direitos democráticos, reatualizando, porém, seus modos de procedimento. Nesse sentido, ganha espaço a idéia de investir nos ritos de passagem, especialmente naqueles promovidos pela escola, tão importantes na vida dos jovens, associando a educação sexual à educação cívica: "Esses ritos ajudariam os jovens a construir sua identidade sexuada e ultrapassar as etapas que levam à idade adulta" (p. 248). Ao contrário dos eventos que estimulam a competitividade e humilham publicamente, a autora defende aqueles que permitem restaurar uma formação humanista sexuada, tendo o Estado como um educador e civilizador.

É de se perguntar, contudo, se os investimentos que Knibiehler defende seriam viáveis na "sociedade de controle", tal como a define Deleuze, em que as instituições agonizam e em que, como quer Foucault, trata-se de lutar não apenas contra o Estado, mas contra as formas de subjetivação impostas aos indivíduos. Refletindo com os/as anarquistas, cujas críticas à sociedade disciplinar e cujas experiências e concepções da sexualidade anteciparam em quase um século a Revolução sexual dos anos 60 , a criação de novas formas de subjetividade, a partir de redes de solidariedade e de amizade pública, demandam a formulação de éticas libertárias, de novos imaginários sociais mais do que a reutilização de espaços simbólicos obsoletos, instituídos pelo Estado, que, em nome da democracia, reforça modos excludentes e hierarquizadores de organização da vida social. Ao invés de renovar os internatos, como sugere a autora, deveríamos ajudar a libertar os jovens, tanto quanto os adultos, de todos os tipos de prisão e dos símbolos que os justificam e consolidam como necessários.

MARGARETH RAGO

Universidade Estadual de Campinas

\section{Quando eu é uma outra}

\section{Jacques e Lotka: uma história da Resistência.'}

YUNG DE PRÉVAUX, Aude.

Rio de Janeiro: Editora Record, 2003. $252 \mathrm{p}$.

Um dos mais clássicos recursos narrativos dos folhetins, sejam eles jornalísticos, sejam eletrônicos, é o da identidade encoberta: por exemplo, uma personagem acredita-se filha biológica de um casal; porém, este, na verdade, apenas a criou. Um belo dia, ela descobre, de modo súbito e impactante, sua efetiva origem, emocionando fortemente os espectadores/ leitores...
Não só através desses folhetins, mas também das seções policiais, tais episódios se fazem presentes na mídia com freqüência, com alguns temperos tecnológicos contemporâneos, como os exames de DNA, feitos a partir da saliva deixada pela pessoa em uma guimba, e de fotos de crianças desaparecidas nos monitores de computador, em um caso de crianças seqüestradas de maternidades e criadas como filhas pela própria seqüestradora, fartamente estampado no noticiário.

Raramente, todavia, produzem uma pequena obra-prima, como Jacques e Lotka, muito além da literatura de massa e do consumo descartável.

Eis a história: Aude, a autora do livro, estava com 23 anos, quando soube, abrupta e casualmente, quem, de fato, ela era.

Na Biblioteca Nacional, em Paris, Aude 